\title{
ALSO AVAILABLE IN PAPERMAC
}

211 The Human Agent Volume I of the Royal Institute of Philosophy's annual lectures is concerned with the concept of man as an agent, a being who acts and reflects on his actions. In what does man's experience of being a free agent consist? Are man's actions caused, and if so, how? Are his deliberations and decisions really no more than his brain processes as they are subjectively apprehended? Can man be free and yet his actions be predictable?

Answering these questions, and related ones in moral philosophy and the philosophy of mind, are G. P. Henderson, Aurel Kolnai, Bernard Mayo, Alan R. White, David Pears, C. H. Whiteley, the Earl of Halsbury, G. N. A. Vesey, R. J. Hirst, C. K. Grant, G. J. Warnock, Gilbert Ryle, and Richard Wollheim.

'There are papers on the perennial problems of freedom and determinism, on the applicability of the notion of causation to numan action, on the mind-body problem and on a number of other matters more loosely connected with the central theme. One who wished to know of the sort of thing discussed by contemporary British philosophers under these heads could not do better than to turn to this book for information.

... There is a generally high level of performance in these papers which makes the volume as a whole one which is very worth while.'-The Times Literary Supplement

A complete list of Papermacs can be obtained by writing to the publishers: Macmillan, Little Essex Street, London, WC2 
What do philosophers make of recent developments in theology? What, now, are we to understand by talk of God, Faith, Sin, Heaven, Hell, Eternal Life? Can we continue to think of God as a supernatural person, or should we accept that such an idea of God is dead? Is to talk of God to give expression to a view of the world, a view in which selfless love is unaccountably seen as supreme? Is Hell the state of separation that exists between a wrong-doer and a person wronged? Is Eternal Life something to be experienced, if at all, in this, our only life?

These are among the questions to which leading philosophers. of religion in Britain, Europe and the U.S.A. addressed themselves in the 1967-68 session of Royal Institute of Philosophy lectures. Agreement would have been too much to expect, when the boundaries, of man's understanding of what he is doing in talking of God, are being pushed back. Bertocci and van Buren, Hartshorne and Hick, Ramsey and Ricoeur represent ways of thinking too far apart for an easy acceptance of each others' arguments. It is not merely the reader who is challenged in this book: the contributors challenge one another. The reader can imagine the liveliness of the discussions which followed the lectures at the Institute's Bloomsbury headquarters. What unites the lectures is not a uniformity of opinion, or even of approach, but a common purpose: to promote mutual understanding of the language of religion.

Talk of God is volume two in the Royal Institute of Philosophy Lecture series. Volume one, The Human Agent, was published by Macmillan in 1968. Volumes three and four will contain lectures on the theory of knowledge, and on the social sciences, respectively. 